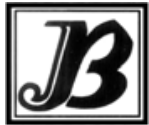

J. bio-sci. 17: 35-40, 2009

ISSN 1023-8654

http://www.banglajol.info/index.php/JBS/index

\title{
BIOCHEMICAL ANALYSIS AND PHYSICOCHEMICAL STABILITY OF A PARTIALLY PURIFIED LECTIN FROM HILSHA EGGS
}

\author{
Imtiaj Hasan ${ }^{*}$, Syed Rashel Kabir, Md Ashraful Haque, Nurul Absar \\ Department of Biochemistry and Molecular Biology, University of Rajshahi, Rajshahi-6205, Bangladesh. \\ ${ }^{1}$ School of Environmental Science and Management, Independent University Bangladesh, Baridhara, Dhaka-1212.
}

\begin{abstract}
Context: Hilsha is one of the most popular fish in Bangladesh. Biochemical analysis of Hilsha egg revealed that it is quite a healthful food. A specific class of proteins called lectins is partially purified from this source.

Objectives: To carry the nutritional analysis of Hilsha eggs and to isolate sugar-specific lectins from the animal source by applying effective purification techniques.

Materials and Methods: The moisture, ash, protein, lipid, polysaccharide, free sugar, cholesterol, calcium, phosphorus and iron contents were determined by the conventional methods and the lectins were isolated by using the affinity chromatographic technique. The effect of temperature, $\mathrm{pH}$ and metal ions were observed by performing the hemagglutination assay.

Results: The moisture, ash, protein, lipid, polysaccharide, free sugar, cholesterol, calcium, phosphorus and iron contents were 34-, 2.4-, 32.59-, 28.35-, 0.036-, 0.059-, 0.40-, 0.178-, 0.193- and 0.136\%, respectively. The partially purified crude protein by affinity chromatography from Hilsha eggs agglutinated rabbit erythrocytes and the hemagglutinating activity is inhibited by $25 \mathrm{mM}$ Raffinose followed by $100 \mathrm{mM}$ of glucose, N-acetyl-D-glucosamine, N-acetyl-D-galactosamine and Dgalactosamine- $\mathrm{HCl}$ each. In the presence of the chelating agent EDTA, the lectin lost its activity completely. Thermal and $\mathrm{pH}$ inactivation assay of the lectin indicates that the activity is highest at 30 to $40^{\circ} \mathrm{C}$ and at the $\mathrm{pH} 5$ to 9 , respectively.
\end{abstract}

Conclusion: Hilsha fish eggs can be recommended as a nutritious food and as well as can be regarded as a source of animal lectins, a group of sugar-binding proteins.

Key words: Nutritional analysis, Hemagglutination assay, Temperature, pH, Tenualosa ilisha.

\section{Introduction}

Hilsa fish (Tenualosa ilisha) is a member of the family Clupeidae, order Clupeiformes. Locally known as 'llish', the fish has been designated as the national fish of Bangladesh. Its unique taste and nutritional value have made it the most popular fish not only in Bangladesh but also in many parts of the world.

The Hilsa is a highly fecund fish. A large-sized female can produce up to 2 million eggs. Lipids are the most abundant dry constituent of most fish eggs in addition to proteins and play a major role as membrane constituent and energy reserves in developing fish embryos. The major lipid classes found in fish eggs are phospolipids and triacylglycerols. Phospholipids can be present in phosphatidylcholine, phosphatidylethanolamine and phosphatidylinositol forms. The Cholesterol content in fish eggs is also high (Mukhopadhyay and Ghosh 2007). The lipids are rich in polyunsaturated fatty acids (PUFAs). Among PUFAs, arachidonic acid (20:4 n-6 AA), Eicosapentaenoic acid (20:5 n-3 EPA) and docosahexaenoic acid

* Corresponding Author: hasanimtiaj@yahoo.co.uk 
(22:6 n-3 DHA) are present. Palmitic acid (16:0) is the most abundant saturated fatty acids present in fish eggs. Fish eggs are rich in PUFAs along with high lipid content in body tissue that makes it not only tasty but also very much essential for human health and membrane development.

Lectins are a group of sugar-binding proteins that recognize specific carbohydrate structures and thereby agglutinate cells by binding to cell-surface glycoproteins and glycocpnjugates (Lis and Sharon 1998). Lectins are found in all types of living organisms, either in soluble or in membrane-bound form. They are usually structurally complex molecules with one or more carbohydrate-recognition domains (Dod and Drickamer 2001). Till now, most of the lectins are purified from plant sources and much smaller numbers from animal sources. A number of egg lectins have been isolated from various fish families such as Salmonidae, Clupeidae, and Cyprinidae (Tateno et al. 1998, Galliano et al. 2003). The present state of knowledge permits us to organize the known animal lectins into several categories depending on sequence similarity and common characteristics such as sugar binding specificity, conserved carbohydrate recognition domains, and ion requirements. So far no such information is available whether or not Hilsha egg contains any such lectin. In order to obtain information regarding the nature of protein present in Hilsha eggs, the present investigation has undertaken. In this paper we are reporting the nutritional analysis of Hilsha eggs and a study relating to the physico-chemical effect on Hilsha egg lectin activity.

\section{Materials and Methods}

Materials: For the experimental purpose, Hilsha fishes (Tenualosa ilisha) were collected from Shaheb Bazar, Rajshahi metropolitan area. The fishes were mainly caught from the Meghna River near Chandpur. Mature eggs were collected from those fishes and was used for experimental purposes. The eggs were not overripe as the overripe eggs have higher lipid content than the ripe eggs.

Nutritional Analysis: The $\mathrm{pH}$ was determined by using a pH meter. The moisture content was determined by the conventional procedure. Ash content was determined by following the method of AOAC (1980). Lipid content of Hilsha eggs was determined by the method of Bligh and Dyer (1959). Protein content was determined with Micro-Kjeldahl apparatus. The starch and free sugar contents were determined by the Anthrone method as described by Jayaraman (1988) and Morse (1949), respectively. Calcium content was determined by the titrimetric method (Sten 1978) while phosphorus content was determined by the method of Boltz (1958). Iron content was determined spectrophotometrically by the thiocyanate method (Vogel 1978).

Crude protein Preparation: Fifty gram of Hilsha eggs was homogenized with $300 \mathrm{ml} 50 \mathrm{mM}$ of tris-HCl buffer containing $0.15 \mathrm{M} \mathrm{NaCl}$ at $4{ }^{\circ} \mathrm{C}$ and centrifuged at $8,000 \mathrm{rpm}$ for 30 minutes. Clear supernatant was used as crude protein extract.

Binding ability of Hilsha egg lectin to affinity column: An affinity column material was prepared by attaching $\mathrm{N}$-acetyl-D-glucosamine and Rhamnose to the Sepharose 4B gel as a matrix by using epicholorohydrine as a cross linker. The column matrix is activated following the usual method and then de-aerated properly. Then the matrix was poured on the column. After washing the column by $10 \mathrm{mM}$ Tris-HCl buffer ( $\mathrm{pH}$ 8.0) containing $0.15 \mathrm{M} \mathrm{NaCl}$, the crude protein was applied to the column. Then the column was washed by the same buffer and the lectin was eluted by using the same buffer containing $0.6 \mathrm{M} \mathrm{N}$-acetyl-D-glucosamine. Finally the eluted fraction was dialyzed against distilled water and TBS and was then subjected for hemmaglutination activity.

Hemagglutination assay: The hemagglutination assay was performed in 96-well microtiter U-bottomed plates. A final volume of $100 \mu \mathrm{l}$ containing $50 \mu \mathrm{l}$ of $2 \%$ suspension of albino rat erythrocytes (previously washed with $0.15 \mathrm{M} \mathrm{NaCl}$ ) and $50 \mu \mathrm{l}$ of two-fold serial diluted lectin solutions were used for the assay. After gentle shaking, the plate was kept at room temperature for 30 minutes. Then the agglutination titer of the maximum dilution giving the positive agglutination was recorded. 
Hemagglutination Inhibition: Inhibition of hemagglutinating activity was examined by adding a serial dilution of sugars like D-glucose, D-galactose, D-Mannose, D-arabinose, D-rhamnose, D-raffinose, Methyl-a-Dgalactopyranoside and $\mathrm{N}$-acetyl-D glucosamine to the incubation mixture. The hemmaglutination activity was checked after 30 minutes.

Temperature and $\mathrm{pH}$ on hemagglutination activity: To examine the thermo stability, crude protein was incubated at $30^{\circ}-80^{\circ} \mathrm{C}$ for 30 minutes. After heat treatment, the protein solutions were centrifuged at 6,000 $\mathrm{rpm}, 4^{\circ} \mathrm{C}$ for 10 minutes, and the clear supernatant was used for detecting the hemagglutination titers against $2 \%$ rabbit erythrocyte. Among the techniques used to establish the conditions for reversible denaturation, the lowering of $\mathrm{pH}$ has become quite common (Itano and Singer 1958). The $\mathrm{pH}$ stability was determined by incubating the crude protein solutions against different buffers ( $\mathrm{pH}$ value ranging from 3 to 11) containing $0.15 \mathrm{M} \mathrm{NaCl}$ for 6 hours at room temperature. The protein solutions were again dialyzed against $20 \mathrm{mM}$ Tris$\mathrm{HCl}$ buffer ( $\mathrm{pH} 7.5$ ) containing $0.15 \mathrm{M} \mathrm{NaCl}$ for 12 hours. The following buffers were used: $50 \mathrm{mM}$ sodium citrate (pH 3.0-5.0), $50 \mathrm{mM}$ sodium phosphate (pH 6.0- 7.0), $50 \mathrm{mM}$ Tris- $\mathrm{HCl}(\mathrm{pH} 8.0)$, and $50 \mathrm{mM}$ glycin$\mathrm{NaOH}(\mathrm{pH}$ 9-11).

Metal ions on hemagglutination activity: To determine the dependency of hemagglutination activity on the divalent cations, the protein was incubated with 0.1 M EDTA for 2 hours at room temperature. The protein solution was dialyzed against $20 \mathrm{mM}$ TBS buffer $(\mathrm{pH} 7.8)$ in presence and absence of $\mathrm{Ca}^{2+}$ for 12 hours at ${ }^{\circ} \mathrm{C}$ and then subjected to the hemagglutination assay.

\section{Results and Discussion}

Nutritional analysis: The pH value of Hilsha eggs was found to be in the basic side of the scale. The moisture content of Hilsha fish egg was recorded as $34 \%$ while the ash content was found to be $2.5 \%$. Protein and lipid content of Hilsha eggs were found to be $32.59 \mathrm{~g}$ and $28.35 \mathrm{~g}$ per $100 \mathrm{~g}$. The amount of polysaccharide and free sugar present were $36.0 \mathrm{mg}$ and $59.0 \mathrm{mg}$ per $100 \mathrm{~g}$ of egg respectively. The cholesterol content was determined to be $400.0 \mathrm{mg}$ per $100 \mathrm{~g}$ of eggs. So, Hilsha egg is a moderate source of cholesterol and the data conforms that the cholesterol content of most fish egg lies in the range of 250 to $650 \mathrm{mg} / 100 \mathrm{~g}$, which is considerably higher than that of fish fillet and much lower than that of bird egg yolk (900-1600 $\mathrm{mg} / 100 \mathrm{~g}$ ) (Iwasaki and Harada 1983). The total calcium, phosphorus and iron content of Hilsha egg were recorded as $178.0 \mathrm{mg}, 193.0 \mathrm{mg}$ and $136.0 \mathrm{mg}$ per $100 \mathrm{~g}$ of eggs respectively. All the results of the nutritional analysis are shown in Table-1.

Binding ability of Hilsha egg lectin to the affinity column: The crude protein extract was found to be bound to the affinity column and the bound fraction was eluted from the column using $10 \mathrm{mM}$ Tris-HCl buffer (pH 8.0) buffer containing $0.6 \mathrm{M} \mathrm{N}$-acetyl-D-glucosamine sugar. The eluted bound fraction gave strong agglunating activity against rabbit erythrocytes.

Hemagglutination and Hemagglutination inhibition assay: Hemagglutination activity $\left(2^{-6}\right)$ of the crude protein extract revealed that Hilsha eggs might contain the lectin proteins. The carbohydrate-binding specificity was evaluated by inhibiting the agglutination of $2 \%$ rabbit erythrocytes using different sugars. The Hemagglutination activity of the bound fraction was inhibited by $25 \mathrm{mM}$ Raffinose followed by $100 \mathrm{mM}$ of glucose, $\mathrm{N}$-acetyl-D-glucosamine, $\mathrm{N}$-acetyl-D-galactosamine and D-galactosamine- $\mathrm{HCl}$ as shown in Table 2. This result indicates that Hilsha egg contains a lectin that may be specific for galactose and glucose. Further study is needed to confirm the sugar specificity specifically for purifying the lectin(s).

Effect of denaturants and divalent ions on Hilsha Egg lectin activity: To examine the effect of divalent cation, $\mathrm{Ca}^{2+}$ as well as chelating agent EDTA were added to the lectin solution separately, and the result showed that the lectin activity was completely abolished in the presence of $100 \mathrm{mM}$ EDTA (Table-3). In presence of 
$\mathrm{Ca}^{2+}$ the hemmaglutinating activity of the lectin enhanced significantly indicating that $\mathrm{Ca}^{2+}$ is vital for the hemagglutination of the Hilsha egg lectin that was released entirely from the lectin after the treatment with EDTA. The inhibitory effect of EDTA on the hemagglunating activity of other lectins such as TM (ToraMame) lectin has also been reported (Itoh et al. 1980).

Effect of Temperature and $\mathrm{pH}$ on hemagglutination activity: Thermal inactivation of the crude lectins was investigated by incubating the protein solution at different temperatures for 30 minutes and assaying the agglutination activity. The obtained result indicates that the lectins retained its activity up to $100 \%$ at $40{ }^{\circ} \mathrm{C}$ but when the temperature was increased to $50^{\circ} \mathrm{C}$, the lectin lost its activity to $88 \%$. It lost its activity almost completely at $70^{\circ} \mathrm{C}$ as shown in Fig. 1. The lectin was found to be stable in the pH value of 5 to 9 . Below and above this pH ranges the lectin drastically lost its activity (Fig. 2).

Effect of metal ions on hemagglutination activity: Many lectins have been reported to be metalloproteins (Goldstein and Hayes 1978) and a part of the metal is necessary for the hemagglutination activity (Tunis 1965), polysaccharide precipitation (Paulova et al. 1971) and lymphocyte transformartion (Takahashi et al. 1971). A new lectin is purified in South Korea from the hard roe of Skipjack Tuna (Katsuwonus pelamis) (Jung et al., 2003). From the present data it can be suggested that the hemagglutinating activity of this lectin is influenced by the $\mathrm{ca}^{2+}$ and that optimum activity was observed at $40^{\circ} \mathrm{C}$ temperature and at a pH range of 6.0-8.5.

In the case of Hilsha egg lectins, calcium $\left(\mathrm{Ca}^{2+}\right)$ may be present in small amounts. This possibility might be supported from the observation that the hemagglutinating activity increased to about $40 \%$ by the addition of $\mathrm{Ca}^{2+}$ to the lectins (Table - 3).

Table 1. Nutritional Analysis of Hilsha eggs

\begin{tabular}{lc}
\hline Studied Parameters & Results \\
\hline $\mathrm{pH}$ & 8.6 \\
Moisture (\%) & $34.00 \pm 0.04$ \\
Ash (\%) & $2.50 \pm 0.03$ \\
Protein (g \%) & $32.59 \pm 0.18$ \\
Lipid (g \%) & $28.35 \pm 0.12$ \\
Cholesterol (g \%) & $0.40 \pm 0.03$ \\
Polysaccharide (g \%) & $0.036 \pm 0.05$ \\
Free sugar (g \%) & $0.059 \pm 0.04$ \\
Calcium (mg \%) & $178.00 \pm 0.04$ \\
Phosphorus (mg \%) & $193.00 \pm 0.04$ \\
Iron (mg \%) & $136.00 \pm 1.08$ \\
\hline
\end{tabular}

Table 2. Inhibition of hemagglutination activity of Hilsha egg lectin by different sugars

\begin{tabular}{lc}
\hline \multicolumn{1}{c}{ Sugar } & MIC $(\mathrm{mM})$ \\
\hline Raffinose & 25 \\
Glucose & 100 \\
N-acetyl-D-glucosamine & 100 \\
N-acetyl-D-galactosamine & 100 \\
D-galactosamine-HCl & 100 \\
D-mannose & - \\
L-Fucose & - \\
L-Rhamnose & - \\
\hline
\end{tabular}


Table 3. Effects of $\mathrm{Ca}^{2+}$ and EDTA on the hemagglutination activities of Hilsha Egg lectin

\begin{tabular}{ccc}
\hline Salts Added & Concentrations $(\mathrm{mM})$ & $\begin{array}{c}\text { Relative Hemagglutinating activity } \\
(\%)\end{array}$ \\
\hline None & - & 100 \\
EDTA & 100 & - \\
$\mathrm{CaCl}_{2}$ & 100 & 140 \\
\hline
\end{tabular}

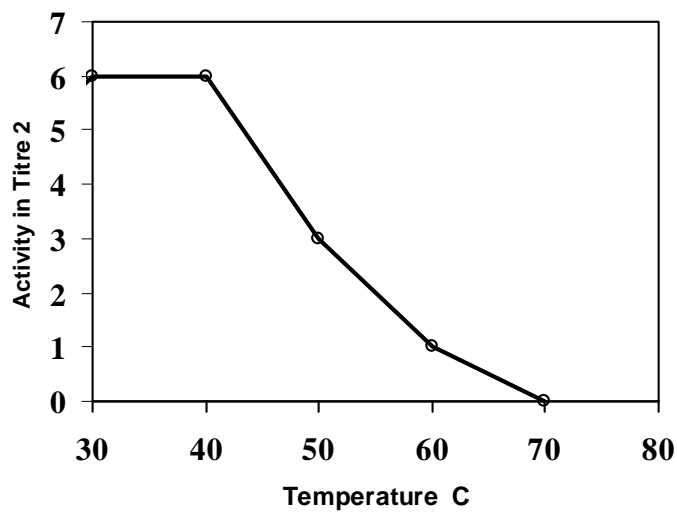

Fig. 1. Effect of temperature on Hilsha egg lectin hemagglutination activity.

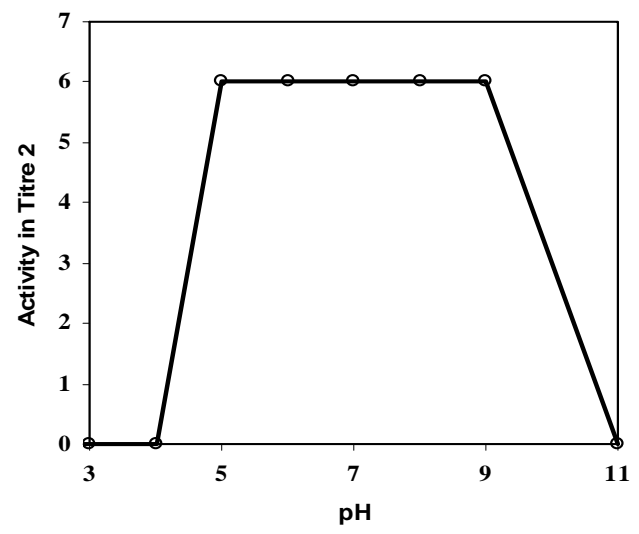

Fig. 2. Effect of $\mathrm{pH}$ on Hilsha fish egg lectin hemagglutination activity.

\section{References}

AOAC. 1980. Methods of Analysis. 13 th Edition., Association of Oficial Analytical Chemists. Washington DC, USA, pp. 122.

Bligh EG, Dyer W. 1959. Total lipid extraction and purification. Can J Biochem Physiol 37, 911-915

Boltz DF. 1958. The Coloremetric Determination of Nonmetals. Inter-Science Pub. Inc, New York.

Dodd RB, Drickamer K. 2001. Lectin-like proteins in model organisms: implications for evolution of carbohydrate-binding activity. Glycobiology 11, 71R-79R. doi:10.1093/glycob/11.5.71R

Galliano M, Minchiotti L, Campagnoli L, Sala A, Visai L, Amoresano A, Pucci P, Casbarra A, Cauci M, Perduca M, Monaco HL. 2003. Structural and biochemical characterization of a new type of lectin isolated from carp eggs. Biochem J 376, 433-440. doi:10.1042/BJ20030413

Goldstein IJ, Hayes CE. 1978. The lectins: Carbohydrate-binding proteins of plants. Adv Carbohydr Chem Biochem 35, 127-340. doi:10.1016/S0065-2318(08)60220-6

Itano HA, Singer SJ. 1958. Dissociation and recombination of human adult hemoglobins A. Proc Nat Acad Sci 10, 349.

Itoh M, Kondo K, Komada H, Izutsu K, Shimabyashi Y, Takahashi T. 1980. Purification and characterization of a lectin from Phaseolus vulguris seed. Agric Biol Chem 44, 125-133.

Iwasaki M and Harada R. 1983. Cholesterol Content of Fish Gonads and Llivers, Bull Jap Soc Sci Fish 50(9), 1623.

Jayaraman J. 1988. Laboratory Manual in Biochemistry. ${ }^{\text {st }}$ Edition, Wiley Eastern Ltd, New Delhi.

Jung WK, Park PJ, Kim SK. 2003. Purification and characterization of a new lectin from the hard roe of Skipjack tuna, Katsuwonus pelamis. Int J Biochem Cell Biol 35 (2), 255-65. doi:10.1016/S1357-2725(02)00176-0 
Lis H, Sharon N. 1998. Lectins: carbohydrate-specific proteins that mediate cellular recognition. Chem Rev 98, 637-674. doi:10.1021/cr940413g

Morse EE. 1949. Anthrone in estimating low concentrations of sucrose. Anal Chem 19, 1012-1013. doi:10.1021/ac60012a021

Mukhopadhyay T, Ghosh S. 2007. Lipid profile and fatty acid composition of two silurid fish eggs. J Oleo Sci 56(8), 399-403.

Paulova MG, Entlcher M, Ticha J, Kosti V, Kocourek J. 1971. Phytohemagglutinins - VII. Effect of $\mathrm{Mn}^{2+}$ and $\mathrm{Ca}^{2+}$ on hemagglutination and polysaccharide precipitation by Phytohemagglutinins- IX. Metal content and activity of the hemagglutinin from the lentil (Lens esculenta moench). Biochimica Biophys Acta 252, 388-395.

Sten MJ. 1978. Analysis of Minerals - A Practical Approach. McGraw-Hill Book Company, New York.

Takahashi T, Shimabayashi Y, Iwomoto K, Leiner IE. 1971. The role of metal ions in the hemag-glutinating activity of the wax bean hemagglutinin. Agric Biol Chem 35, 1274-1279.

Tateno H, Saneyoshi A, Ogawa T, Muramoto K, Kamiya H, Saneyoshii M. 1998. Isolation and characterization of rhamnose-binding lectins from eggs of steelhead trout (Oncorhynchus mykiss) homologous to low density lipoprotein receptor superfamily. J Biol Chem 273(30), 19190-19187. doi:10.1074/jbc.273.30.19190

Tunis M. 1965. The inhibitory action of EDTA on erythrocyte agglutination by lectins. J Immunol 95, 876-879.

Vogel Al. 1978. Vogel's Text book of quantitative in organic analysis. $4^{\text {th }}$ Edition., Longman Group Limited. 